\title{
The health care experience of individuals with morbid obesity assisted in public healthcare services*
}

\author{
O cuidado experienciado por pessoas com obesidade \\ mórbida nos serviços públicos de saúde \\ El cuidado experimentado por personas obesas mórbidas \\ en los servicios públicos de salud
}

How to cite this article:

Conz CA, Jesus MCP, Kortchmar E, Braga VAS, Oliveira DM, Merighi MAB. The health care experience of individuals with morbid obesity assisted in public healthcare services. Rev Esc Enferm USP. 2020;54:e03559. doi: https://doi.org/10.1590/S1980-220X2018049903559

\section{Claudete Aparecida Conz ${ }^{1}$ \\ Maria Cristina Pinto de Jesus ${ }^{2}$ \\ Estela Kortchmar ${ }^{1}$ \\ Vanessa Augusta Souza Braga ${ }^{1}$ \\ Deíse Moura de Oliveira ${ }^{3}$ \\ Miriam Aparecida Barbosa Merighi $^{4}$}

* Extracted from the thesis: "A busca pela cirurgia bariátrica: itinerário terapêutico vivido no Serviço Público de Saúde”, Escola de Enfermagem, Universidade de São Paulo, 2019.

${ }^{1}$ Universidade de São Paulo, Escola de Enfermagem, Programa de Pós-Graduação em Enfermagem, São Paulo, SP, Brazil.

${ }^{2}$ Universidade Federal de Juiz de Fora, Faculdade de Enfermagem, Departamento de Enfermagem Básica, Juiz de Fora, MG, Brazil.

${ }^{3}$ Universidade Federal de Viçosa, Departamento de Enfermagem e Medicina, Viçosa, MG, Brazil.

${ }^{4}$ Universidade de São Paulo, Escola de Enfermagem, Departamento de Enfermagem Materno-Infantil e

Psiquiátrica, São Paulo, SP, Brazil.

\section{ABSTRACT}

Objective: To understand the health care experience of individuals with morbid obesity assisted in public healthcare services. Method: This was a qualitative study based on Alfred Schütz's social phenomenology, carried out in the medical-surgical clinic of a public hospital in São Paulo, Brazil. Interviews with open questions were conducted between January and April 2017. Results: Seventeen individuals with morbid obesity participated in the study. The findings revealed care(lessness) experiences of obese individuals in the Brazilian Healthcare System in terms of structure/logistics and human resources. Study participants shared care expectations about health care management and staff, and further considered the Primary Health Care service as a scenario of power to have their obesity-related care needs met. Conclusion: The findings need to be carefully (re)examined by the healthcare system's micro- and macro management, as well as by health teaching and research personnel, in order to integrate, follow up and qualify care actions towards the prevention and control of obesity in public healthcare services.

\section{DESCRIPTORS}

Obesity; Health Services; Comprehensive Health Care; Nursing Care; Qualitative Research. 


\section{INTRODUCTION}

Obesity is a multifactorial chronic disease which has long been a topic of concern worldwide. The multiple factors contributing to the onset of the disease should be a target of political interventions and healthcare strategies executed by a qualified multidisciplinary team ${ }^{(1)}$.

The Brazilian Ministry of Health has launched obesity prevention and management policies which have gained worldwide recognition, for instance, the definition of obesity as a priority line of care in the Health Care Network (HCN) for people with chronic diseases, and the adoption of the "Primary Care Notebook", which focuses on obesity as a chronic disease ${ }^{(2)}$.

While evidence-based publications on the disease control and management have had a steady increase over the last decades, obesity prevalence rates remain growing exponentially in Brazil and across the globe. In countries like Australia, Canada, Chile, South Africa and the United Kingdom, more than one in four adults is obese ${ }^{(3)}$. In the United States (U.S.), according to data from the Behavioral Risk Factors Surveillance System, adult obesity rates exceed $35 \%$ in seven states, $30 \%$ in 29 states and $25 \%$ in 48 states. West Virginia had the highest adult obesity rate (38.1\%) whereas Colorado had the lowest (22.6\%). Between 2016 and 2017, adult obesity rates increased in Iowa, Massachusetts, Ohio, Oklahoma, Rhode Island and South Carolina, and remained stable in the other U.S. states ${ }^{(4)}$.

In Brazil, the surveillance system for risk and protective factors for chronic diseases showed through a telephone survey (Vigitel) that adult obesity rates varied between 15\% in Florianópolis and 23.8\% in Manaus. Considering pooled data of all capitals, the frequency of obese adults in 2017 was $18.9 \%$, with no difference between the sexes ${ }^{(5)}$.

The high prevalence of obesity worldwide makes it a global public health issue. Longitudinal care actions are constantly needed for health surveillance, as the environment where people live, and their lifestyles, may trigger the onset of obesity or aggravate its course in obese individuals ${ }^{(1)}$. Hence, action plans for obesity control must be priority-driven according to people's contexts, involving them in order to incorporate planned actions ${ }^{(6)}$. Obese individuals need to understand their chronic condition and take part of an educational and motivational care plan to achieve the desired weight.

However, there remains a gap in this field on the part of healthcare services and obese individuals, which renders obesity care extremely difficult to perform. A study carried out in the United States with obese people, health professionals and managers, found that $54 \%$ of people with obesity feared that their weight could affect their future health condition, $50 \%$ considered themselves obese, $55 \%$ reported receiving a formal diagnosis of obesity, and $24 \%$ of them had a follow-up appointment scheduled to address weight-related issues. This study further revealed that not all health professionals felt responsible for contributing to encourage weight loss, and only $18 \%$ of the managers felt partly accountable for the disease control ${ }^{(7)}$.
Healthcare services may have hurdles troubling a more comprehensive and continuous care plan for overweight people, among which are the lack of interprofessional integration, and misconceptualization and misrecognition of obesity as a chronic condition by health professionals. Altogether, these aspects contribute to the low proactivity of healthcare personnel and their lack of engagement to assist obese individuals ${ }^{(8)}$.

These issues not only can make it difficult to manage obesity but can also aggravate the condition and increase the risk of comorbidities. Morbid obesity, which is characterized by a Body Mass Index equal to or above $40 \mathrm{~kg} / \mathrm{m}^{2(9)}$, is a direct result of gradual worsening of obesity that requires special care by health professionals within the $\mathrm{HCN}$.

The subjectivity of people experiencing obesity who seek care in public health services remains unexplored, particularly among those with morbid obesity. This reinforces the importance of further research focusing on the perspective of obese individuals about the care delivered. These findings may contribute to a better understanding of their needs and expectations throughout a longitudinal coexistence with the disease.

Thus, this study raises the following questions: How do people with morbid obesity experience the care delivered in the public health network? How would they like to be cared for? The reasoning for this study was to provide evidence to enhance the care practices for people with obesity, contributing to bridge the gap between the care experienced by them and what is advocated in health policies and programs. This study aimed to understand the care experience of individuals with morbid obesity assisted in public healthcare services.

\section{METHOD}

\section{Study Design}

This is a qualitative study using Alfred Schütz's social phenomenology as a theoretical-methodological framework. This article was prepared following the recommendations of the Consolidated Criteria for Reporting Qualitative Research (COREQ) ${ }^{(10)}$.

\section{THEORETICAL-METHODOLOGICAL FRAMEWORK}

Alfred Schütz's social phenomenology is based on the human being who lives and acts in the social world. Action is considered to be the core of social life, as it is through which that humans, imbued with a purpose, are encouraged to transform themselves and their social reality ${ }^{(11)}$. The set of existential reasons ("reasons for" and "reasons why") translates the intentional flow of human experience into common sense and expresses through intersubjective relationships the possibility for people to identify and to be identified in a given social group. The "reasons for" reflect the purpose that the action should promote, therefore referring to the future (subjective category). The "reasons why" refer to the experiences lived in the past and present, which create foundations for action projection in a particular reality (objective

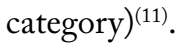




\section{STUdY SCENARIO}

This study was carried out in the medical-surgical clinic of a large public hospital in São Paulo, which has about 2,500 beds. Patients who are scheduled for bariatric surgery are admitted to this unit on average 7 to 10 days before the date of surgery. During this period, patients are assisted by a multidisciplinary team, with the purpose of being prepared not only for the surgery itself, but also for dietary re-education and weight loss.

\section{Selection CRITERIA}

The inclusion criteria consisted of individuals with morbid obesity, admitted to the medical-surgical clinic, aged 18 years or older, with scheduled bariatric surgery, who sought treatment for obesity in public healthcare services.

\section{Data collection}

Prior to the interviews, the researcher established an interaction with the patients to interpret and reflect on the meaning of verbal and non-verbal expressions at the time of data collection. Therefore, an initial approach was made, with clarifications about the study and subsequent invitation to participate. Those willing to participate were scheduled for data collection on the most convenient day and time. Sample selection was intentional, and none of the patients declined participation.

The interviews were conducted from January to April 2017 at the medical-surgical clinic, in a private room which was made available by the inpatient unit head nurse. The interviews were guided through the following questions: considering your experience with obesity and the fact that you are in the preoperative period of bariatric surgery, talk about your experience while seeking care assistance and how you would like to be cared for in the public healthcare services.

The interviews were audio recorded upon participants' consent. The interviews, transcription, and data analysis were carried out by the study coordinator, who was enrolled in a Ph.D. program then. The average length of the interviews was 45 minutes. To ensure the confidentiality of the information and participant's anonymity, the interviewees were identified by the letter P, as in "participant", followed by Arabic numerals according to the order of the interviews (P1 to P17). Data collection ended when a convergence of meaning, with content repetition, was perceived. This indicated that the objective of the study was achieved and that the study questions had been answered, as recommended by the principles of qualitative research ${ }^{(12)}$. No testimony was excluded from analysis.

\section{Data analysis}

The steps proposed by a social phenomenology study published elsewhere ${ }^{(13)}$ were adopted for the organization, categorization and analysis of the meanings of the interviews. Interview transcripts were read in full and the excerpts that presented common aspects of meanings related to the "reasons why" and "reasons for" the care experienced by people with obesity were transcribed and grouped into thematic categories. The set of categories was discussed in the light of Alfred Schütz's social phenomenology concepts and thematic literature.

\section{ETHICAL ASPECTS}

This study was previously approved by the Research Ethics Committee at the Universidade de São Paulo (1.915.867/2017) and at the hosting public hospital (protocol no. 1.956.427/2017). All volunteers signed an informed consent form to authorize their participation. This study complies with all ethical guidelines on research involving human beings contained in the National Health Council's Resolution 466/2012 $2^{(14)}$.

\section{RESULTS}

Seventeen individuals with morbid obesity participated in this study - four males and thirteen females, aged 18 to 70 years, with schooling ranging from primary school to higher education. Participants' Body Mass Index ranged from 40.44 to $80.89 \mathrm{~kg} / \mathrm{m}^{2}$.

The analysis of interview transcripts according to Alfred Schütz's social phenomenology revealed three categories. The first refers to past and present experiences and is related to the "reasons why" individuals with morbid obesity looked for care assistance in the HCN: "Care-related barriers experienced by obese individuals within public healthcare services". The second and the third categories reveal patients' expectations on care assistance in the HCN ("reasons for"): "Desire for comprehensive and qualified care in the healthcare network" and "Actions in the scope of healthcare management and services".

\section{CARE-RELATED bARRIERS EXPERIENCED bY OBESE INDIVIDUALS WITHIN PUBLIC HEALTHCARE SERVICES}

While seeking assistance for obesity, participants reported that they faced scarcity of resources in public healthcare services:

(...) there is no money, government resources are lacking. (...) I expected a little more from the city government, because if there was some collaboration between the governments, there would be no queue, wait. There are people who stay in line for more than 12 years $(\mathrm{P} 2)$.

(...) in the healthcare system, other than here, there is no resource (...) I have been to many health care facilities, health unit, and did not perceive appropriate conditions for them to assist me (P4).

(...) as there are few spots available in public hospitals, the government could invest in agreements with private hospitals, because that way more people would be assisted (P10).

According to the interviewees, the lack of a specialized approach towards individuals with obesity in the context of the Primary Health Care (PHC) negatively impacted the care delivered to them:

(...) at the health unit, they said I was obese and they ordered me not to eat, they never did anything for me, they told me to go on a diet; I have done it all my life, and it was no use (P1). 
At the unit, they never looked at my obesity. (...) nobody told me where and who to look for to help me lose weight (P7).

(...) I missed having a professional to look at me, to guide me. That would have helped me a lot (P13).

(...) I will not continue to follow up at the center because I felt abandoned. (...) the psychologist who was just admitted discharged me, she didn't want to talk to me (P15).

The difficulties associated with obesity-related care in public healthcare services led participants to look for private assistance:

(...) I looked for help at health units, I went to private doctors, I took medicine and nothing worked (P1).

(...) I started going to the health units (...) the endocrinologist gave me medicine to lose weight, but I couldn't keep it up. (...) my mother took me to a private clinic, one of those that apply carboxy (P13).

\section{DESIRE FOR COMPREHENSIVE AND QUALIFIED CARE IN THE HEALTHCARE NETWORK}

Prior to bariatric surgery, participants expect to be assisted by professionals properly trained to meet their needs throughout the HCN:

(...) after surgery, when I am discharged, I will attend follow up at the health unit, but I hope there will be physical structure and trained professionals to receive me, respectfully assist and follow me up. (...) there needs to be more qualified professionals guiding us to make this exchange between doctor and patient (P1).

(...) I would like to see a professional in whom I could trust and follow to get things worked out, it could even be someone from the health unit, to follow me up, to help me continue the treatment, this would make a difference in my life (P7).

(...) it would be very good if I were assisted by a nutritionist, together with a psychologist, to help me not only with the surgery, but with follow-up, at least in the coming years and, if possible, for the rest of my life (P9).

(...) once surgery is done, I hope to continue being seen by all the professionals who assisted me at the Hospital of Clinics. (...) I started off at the health unit, then came here, continued the treatment (P11).

(...) I hope to be able to go back to the primary care unit near home and be assisted by the professionals there, I think it is important (P12).

Patients expect that health actions focused on primary care can help them in the care of obesity:

(...) there could be many lectures for the obese and they should be told why it is important to lose weight. (...) a multidisciplinary team to care for the obese person, who looks at us as human beings, without criticism (P3).

(...) it would be very good if we had an active Family Health Program, with trained professionals, who would visit the households at least once a week, once a month (P5).
(...) health units have to be prepared, hold meetings, support patients, with nurses, psychologists, physical trainers (...) have different service hours to welcome people, so that people do not reach a greater level of obesity as I did (P8).

(...) I wish there were treatment groups for obese people at the health unit. (...) to clarify questions, talk about diets, physical exercise (...) every health unit could do a census in the neighborhood to find out how many are obese (P9).

\section{ACTIONS IN THE SCOPE OF HEALTHCARE MANAGEMENT AND SERVICES}

Participants expect managers to take solid actions for the care of the obese person, as well as to provide comprehensive professional assistance and improvements in the structure of public HCN services:

(...) the city government could make a better hospital to serve patients with severe obesity, and the health unit should count on a professional team to help us at all times when seeking treatment (P2).

(...) that health units have physical structure, because when it gets quite uncomfortable if we have to sit down. Every place is adapted for the skinny but not for the fat person, there is not even a scale to weigh fat people (P4).

(...) the health unit should keep a copy of my medical records and be aware of my case to support me (...) if this exchange existed, $I$ would not have to go for an appointment (P5).

(...) the health unit should refer obese people to referral hospitals, this would help reduce the time required to make an appointment and to schedule surgery. (...) that would speed up the process (P6).

(...) make consortia with private hospitals, because it would attract more people to bariatric surgery, this should be encouraged (P10).

Health managers should be more committed (...) they need to get off the ground, not just write policies, but put them into practice. (...) take action, invest in prevention and treatment (...) invest in bealth rather than disease (P14).

(...) some aspects in the healthcare system could improve care, for example, during this interval that I waited in line for bariatric surgery, I could have continued to do the treatment at the health unit with the endocrinologist and other professionals. Because, here, in the hospital, they can't handle it. (...) there should be an articulation between the hospital and the health unit for surgery waiting lines (P16).

One interviewee reported that the primary care nurse could be a reference professional in the service:

(...) there should be a professional who was a reference for me, in whom I could trust and follow to make everything work out, it could be someone from the health unit, a nurse, to accompany me to help me continue. This would make a difference in my life (P7).

\section{DISCUSSION}

The perception of the person with obesity on the care experience in public healthcare services is based on their 
social background and portrays intersubjective relationships with their daily life people and professionals who are part of the care itinerary. The lack of resources in healthcare services and of a special professional approach for obesity care, together with the need to reach out to private care services, refer to past and present experiences, termed in Alfred Schütz's social phenomenology as "reasons why"(11).

Within the context of "reasons why" there is a whole collection of knowledge and experiences ${ }^{(11)}$ that the person with morbid obesity has encountered while living with the disease, focused herein on the experience of (neglected) care in health services.

When looking for obesity care in public healthcare services, study participants perceived a lack of resources within the Brazilian Healthcare System. Due to its chronic nature, obesity entails continued care, which should be provided through funding and management. A study discussing public spending on health care showed that the proper functioning of a country's health system depends heavily on compatible funding and adequate management of the resources. This presumption remains challenging in $\mathrm{Brazil}^{(15)}$ and considerably impacts obesity care.

The participants also referred to the lack of a professional look directed at the person with obesity by the multidisciplinary team, in order to guide them and implement weight loss strategies. This is a critical aspect of obesity management. As the disease evolves gradually, health professionals should create a care plan to prevent the condition from aggravating. While visiting healthcare services, the study participants were reportedly left without professional attention, which may have contributed to the onset of morbid obesity.

Health professionals are expected to propose and implement individual and collective strategies for the obese person through consultations, home visits, educational groups, among other activities. The patient's compliance with obesity care requires professional sensitivity to consider the context where the obese person lives and, if possible, to include their family in the care plan ${ }^{(16)}$.

An American study carried out with primary care professionals dealing with people with obesity perceived a need for creating a strategic model of integrated care with recommendations and guidelines to qualify the personnel and, consequently, to improve care delivery to the obese population. The performance of the primary care team along with patients' compliance were reported to be essential for professionals to manage patient weight ${ }^{(17)}$.

The difficulties encountered in the search for obesity care led participants to reach out to private healthcare services. While investigating the practicability of access to healthcare services in Brazil, a previous study showed that public-private service connections are numerous and that patient's long wait for specialist care in the public service was the main reason for reaching out to private services ${ }^{(18)}$.

Study participants brought about expectations regarding their biographical situation ${ }^{(11)}$ within a context marked by lack of resources in public health services and by professionals who misdelivered obesity care. The biographical condition of "being morbidly obese in the preoperative period of bariatric surgery" allows patients to reflect on how they and other obese people might expect to be cared for, from the perspective of their own care itineraries within the health services context. Alfred Schütz's social phenomenology states that projection of perspectives in a shared component of interpersonal relationships constitutes a product of intersubjectivity (locus of the meaning of social action) $)^{(11) .}$

Obese individuals expect to have their care needs met in public healthcare services. They expect to be assisted by trained professionals in relation to the development of disease's control actions and that these specific management actions are supervised in the scope of healthcare services ("reasons for").

The expectation for professional care identified in the participants' speeches is permeated by a perspective of networked care. That is, they envisioned being fully cared for in the different healthcare system facilities during their itinerary after bariatric surgery. In their verbalizations, patients emphasized the importance of follow-up in primary care center both for follow-up of bariatric surgery patients and for obese people in general. Consistent with this, the literature states that communication with, and proximity to the primary care team can directly impact weight loss outcomes in obese individuals. In this scenario, the follow-up care and bond of trust existing between the caregiver and the person being cared for are important aspects to consider ${ }^{(19)}$.

Participants' expectations regarding obesity care are in line with what is proposed in the health care model program for chronic conditions, which states that primary care services must coordinate care. However, scientific evidence shows that, in practice, such a model still faces implementation issues. A previous study analyzed the therapeutic itinerary of patients with obesity admitted to the high complex hospital care service at Oeste do Paraná University Hospital, Brazil. The authors demonstrated that although primary care services are considered to be the backbone of the $\mathrm{HCN}$ for providing longitudinal care, their accountability to such role is deficient, which negatively impacts the resolution of the health needs of people with chronic diseases ${ }^{(20)}$.

An intervention study carried out in Brazilian primary care facilities reiterates the problem of networked care processes, by bringing users, their rights, deficiencies and territorial demands to the center of the discussion. The study identified a flawed healthcare network structure and the provision of fragmented care, with little emphasis on health promotion. The authors stressed the importance of recognizing the user and support networks for implementation of health actions ${ }^{(21)}$.

The valuation of obesity care must be associated with professional qualification, as highlighted by interviewers. The $\mathrm{HCN}$ is not made up only by networked processes and structures, but fundamentally by people, whose role is to provide an effective management of obesity care.

A demand for joint actions in the scope of management and health services aimed at people with obesity was another expectation of study participants, as well as improvements in the structure of public health services. To accomplish this, the care needs of obese individuals should be surveyed 
so that follow-care care can be provided in terms of weight control, preparation for bariatric surgery (if indicated) and preventive educational practices ${ }^{(22)}$.

The participants' expectations on how they would like to be cared for by health managers and services reveal dilemmas regarding the doctrinal principles of the Brazilian healthcare system. The desire for larger hospitals and consortia with the private network to serve people with obesity unveils their experience in the quest for universal care. The difficult access to public health services for obesity care demonstrates that the system has not met the health demands of obese individuals. The $\mathrm{HCN}$ physical structure neglects the equity principle due to the carelessness about elementary issues, such as providing appropriate seats for obese people. The organization of the services and the healthcare team are also affected to the extent that obesity care is not continued, nor comprehensive, at all system levels.

In this study, participants unveiled demands within the scope of macro and micromanagement for greater integration and effectiveness of the set of measures for the prevention and control of obesity. As it stands, the HCN includes an obesity care program, which is yet be more implemented, considering the SUS's principles. Hence, primary care actions and the service network organization should be steadily supported, highlighting the importance of intra-sectoriality in the Brazilian public healthcare system ${ }^{(2)}$.

One of the participants reported a preference for a reference nurse for follow up of obese individuals in primary care services. In an attempt to address health-related issues in the community, especially those arising from chronic conditions, there has been a consistent interest in the adoption of innovative and restructuring practices within the healthcare system, with an emphasis on primary care. Advanced nursing practice has been considered one of these innovations ${ }^{(23)}$, broadening the nurse's reference role in obesity care within healthcare services.

To perform advanced practice, the nurse must integrate research, training, care practice, and management skills, thereby demonstrating professional autonomy and competence to make clinical decisions, perform assessments, diagnose, prescribe, conduct case management, evaluate and implement care programs and action plans, and refer users to other healthcare services ${ }^{(22)}$. These actions place the nurse within the scope of the interdisciplinary team as a reference professional in obesity care in terms of prevention and treatment.

The results of this study allowed us to access the itinerary traveled by obese people to have their health needs met within the healthcare system. Alfred Schütz's social phenomenology helped to understand the "reasons why" and the "reasons for" in the care itinerary experienced by study participants. According to the interviewees, the social responses expected from the healthcare system were noticeably late, and their obesity condition progressed to the extent that bariatric surgery was indicated. Of note, the "reasons for" refer to projections of care envisioned by obese individuals which must be translated as social responses to be addressed by the system from the moment they undergo bariatric surgery.

This reinforces the need for continued actions, particularly primary care, which are expected by obese people assisted in public healthcare services. It also reiterates their understanding that bariatric surgery is the best treatment option in their biographical situation, but it is not a guarantee of success in controlling obesity. There must be longitudinal co-responsibility of the actors involved in obesity care programs for care needs to be met, on the part of managers (responsible for $\mathrm{HCN}$ planning and organization) and health team (responsible for operating care in the various healthcare system sectors).

This study reflects the care experience of a group of individuals with morbid obesity who sought treatment in public healthcare services and were awaiting bariatric surgery in a large hospital in the city of São Paulo. Due to sample specificities and the study design, the outcomes presented herein cannot be extrapolated to other population groups.

Taken altogether, these findings may contribute to the knowledge in the field of health and nursing on the intersubjective experience of obese individuals in the quest for care. The difficulty of public health services in providing solutions to the health demands faced by this population was further discussed.

\section{CONCLUSION}

The present study demonstrated care(lessness) experiences of obese individuals and their care itinerary within the healthcare system in terms of structure and human resources, which might have contributed to aggravating their condition. Previous experiences, added to the condition of being morbidly obese, allowed them to raise expectations of care involving management and health team, with the primary care level being a potential scenario chosen by them to respond to obesity-related health needs.

The points raised herein concern a specific social group and need to be carefully (re)examined by the healthcare system's micro- and macro management, as well as by health teaching and research personnel, in order to integrate, follow up and qualify care actions towards the prevention and control of obesity in public healthcare services.

\section{RESUMO}

Objetivo: Compreender o cuidado experienciado por pessoas com obesidade mórbida nos Serviços Públicos de Saúde. Método: Pesquisa qualitativa ancorada no referencial da fenomenologia social de Alfred Schütz, realizada na clínica médico-cirúrgica de um hospital público de São Paulo. Realizaram-se entrevistas com questões abertas entre janeiro e abril de 2017. Resultados: Participaram do estudo 17 pessoas com obesidade mórbida. Os achados mostraram experiências de (des)cuidado para com pessoas obesas nos caminhos percorridos no sistema de saúde, tanto no quesito estrutural quanto no tocante aos recursos humanos no Sistema Único de Saúde. Diante disso, estas pessoas lançam expectativas de cuidado envolvendo a gestão e os profissionais de saúde, tendo sido a Atenção Primária à Saúde o cenário de potência eleito pelos participantes para dar respostas às necessidades de saúde implicadas na obesidade. Conclusão: Os resultados desta investigação carecem de ser criteriosamente (re)avaliados pela micro e macrogestão do sistema, bem 
como pelo ensino e pesquisa na saúde, no sentido de integralizar, longitudinalizar e qualificar as ações cuidativas para a prevenção e o controle da obesidade nos serviços públicos de saúde.

\section{DESCRITORES}

Obesidade; Serviços de Saúde; Assistência Integral à Saúde; Cuidados de Enfermagem; Pesquisa Qualitativa.

\section{RESUMEN}

Objetivo: Comprender el cuidado experimentado por personas obesas mórbidas en los Servicios Públicos de Salud. Método: Investigación cualitativa anclada en el marco de referencia de la fenomenología social de Alfred Schütz, llevada a cabo en la clínica médico-quirúrgica de un hospital público de São Paulo. Se realizaron entrevistas con preguntas abiertas entre enero y abril de 2017.

Resultados: Participaron en el estudio 17 personas obesas mórbidas. Los hallazgos mostraron experiencias de (des)cuidado a las personas obesas en los caminos recurridos en el sistema sanitario, tanto en el marco estructural como en lo que se refiere a los recursos humanos en el Sistema Único de Salud. Frente a eso, dichas personas lanzan expectativas de cuidado que abarcan la gestión y a los profesionales sanitarios, habiendo sido la Atención Primaria de Salud el escenario de potencia elegido por los participantes para dar respuestas a las necesidades sanitarias implicadas en la obesidad. Conclusión: Los resultados de esa investigación carecen de (re)evaluarse con juicio por la micro y macrogestión del sistema, así como por la enseñanza e investigación sanitarias, a fin de integrar, longitudinalizar y cualificar las acciones cuidadoras para la prevención y el control de la obesidad en los servicios públicos sanitarios.

\section{DESCRIPTORES}

Obesidad; Servicios de Salud; Atención Integral de Salud; Atención de Enfermería; Investigación Cualitativa.

\section{REFERENCES}

1. Jones JL, Sundwall D. Health care systems and national policy role of leadership in the obesity crisis. Prim Care. 2016;43(1):19-37. DOI: http://dx.doi.org/10.1016/j.pop.2015.08.008

2. Dias PC, Henriques P, Anjos LA, Burlandy L. Obesity and public policies: the Brazilian government's definitions and strategies. Cad Saúde Publica. 2017;33(7):e00006016. DOI: http://dx.doi.org/10.1590/0102-311x00006016

3. Organization for Economic Co-operation and Development. OECD Obesity Update [Internet]. Paris; 2017 [cited 2019 Mar 27]. Available from: http://www.oecd.org/health/health-systems/Obesity-Update-2017.pdf

4. Center for Disease Control and Prevention. Prevalence of self-reported obesity among U.S. adults by State and Territory, BRFSS, 2017 [Internet]. New York: CDC; 2019 [cited 2019 Mar 19]. Available from: https://www.cdc.gov/obesity/data/prevalence-maps.html

5. Brasil. Ministério da Saúde, Departamento de Vigilância de Doenças e Agravos não Transmissíveis e Promoção da Saúde. Vigitel Brasil 2017: vigilância de fatores de risco e proteção para doenças crônicas por inquérito telefônico. Estimativas sobre frequência e distribuição sociodemográfica de fatores de risco e proteção para doenças crônicas nas capitais dos 26 estados brasileiros e no Distrito Federal em 2017 [Internet]. Brasília; 2018 [citado 2019 mar. 19]. Disponível em: http://bvsms.saude.gov.br/bvs/publicacoes/vigitel_brasil_2017_ vigilancia_fatores_riscos.pdf

6. Rego ALC, Cruz GKP, Carvalho DPSRP, Azevedo IC, Vitor AF, Ferreira Júnior MA. Waiting time of patients in the queue to carry out bariatric surgery and related complications. J Nurs UFPE on line. 2017;11 Supl. 2:1025-31. DOI: http://dx.doi.org/10.5205/reuol.10263-915681-RV.1102sup201719

7. Kaplan LM, Golden A, Jinnett K, Kolotkin RL, Kyle TK, Look M. Perceptions of barriers to effective obesity care: results from the national action study. Obesity. 2018;26(1):61-9. DOI: http://dx.doi.org/10.1002/oby.22054

8. Hayes S, Wolf C, Labbé S, Peterson E, Murray S. Primary health care providers' roles and responsibilities: a qualitative exploration of 'who does what' in the treatment and management of persons affected by obesity. J Comm Healthcare. 2017;10(1):47-54. DOI: http://dx.doi. org/10.1016/j.pcad.2017.02.004

9. Malta DC, Santos MAS, Andrade SSCA, Oliveira TP, Stopa SR, Oliveira MM, et al. Tendência temporal dos indicadores de excesso de peso em adultos nas capitais brasileiras, 2006-2013. Ciênc Saúde Coletiva. 2016;21(4):1061-9. DOI: http://dx.doi.org/10.1590/141381232015214.12292015

10. Tong A, Sainsbury P, Craig J. Consolidated criteria for reporting qualitative research (COREQ): a 32 -item checklist for interviews and focus groups. Int J Qual Health Care. 2007;19(6):349-57. DOI: https://doi.org/10.1093/intqhc/mzm042

11. Schütz A. Sobre fenomenologia e relações sociais. Petrópolis: Vozes; 2012.

12. Minayo MCS. Amostragem e saturação em pesquisa qualitativa: consensos e controvérsias. Rev Pesq Qualitat [Internet]. 2017 [citado 2019 mar. 28];5(7):1-12. Disponível em: https://editora.sepq.org.br/index.php/rpq/article/view/82/59

13. Kortchmar E, Merighi MAB, Conz CA, Jesus MCP, Oliveira DM. Weight regain after bariatric surgery: a phenomenological approach. Acta Paul Enferm. 2018;31(4):417-22. DOI: http://dx.doi.org/10.1590/1982-0194201800058

14. Brasil. Ministério da Saúde. Resolução n. 466, de 12 de dezembro de 2012. Dispõe sobre diretrizes e normas regulamentadoras de pesquisas envolvendo seres humanos [Internet]. Brasília; 2012 [citado 2019 mar. 28]. Disponível em: http://conselho.saude.gov.br/ resolucoes/2012/reso466.pdf

15. Saldiva PHN, Veras M. Gastos públicos com saúde: breve histórico, situação atual e perspectivas futuras. Estud Av. 2018;32(92):4761. DOI: http://dx.doi.org/10.5935/0103-4014.20180005

16. Oliveira DM, Merighi MAB, Jesus MCP. The decision of an obese woman to have bariatric surgery: the social phenomenology. Rev Esc Enferm USP. 2014;48(6):970-6. DOI: http://dx.doi.org/10.1590/S0080-623420140000700002

17. Kushner RF, Kahan S. Introduction: the state of obesity in 2017. Med Clin N Am. 2018;102(1):1-11. DOI: http://dx.doi.org/10.1016/j. mcna.2017.08.003

18. Meneses CS, Cecilio LCO, Andreazza R, Carapinheiro G, Andrade MGG, Santiago SM, et al. Lay agency and the generation of publicprivate mix health care maps. Ciênc Saúde Coletiva. 2017;22(6):2013-24. DOI: http://dx.doi.org/10.1590/1413-81232017226.14822016 
19. Puente JMG, Martínez-Marcos M. Sobrepeso y obesidad: eficacia de las intervenciones en adultos. Enferm Clin. 2018;28(1):65-74. DOI: https://doi.org/10.1016/j.enfcli.2017.06.005

20. Younes S, Rizzotto MLF, Araújo ACF. Therapeutic itinerary of patients with obesity treated in high-complexity services of a university hospital. Saúde Debate. 2018;41(115):1046-60. DOI: http://dx.doi.org/10.1590/0103-1104201711505

21. Maximino VS, Liberman F, Frutuoso MF, Mendes R. Professionals as networks producers: compositions and connections in health care. Saúde Soc. 2017;26(2):435-47. DOI: http://dx.doi.org/10.1590/s0104-12902017170017

22. Almeida LM, Campos KFC, Randow R, Guerra VA. Estratégias e desafios da gestão da atenção primária à saúde no controle e prevenção da obesidade. Rev Eletr Gestão Saúde. 2017;8(1):114-39.

23. Miranda Neto MV, Rewa T, Leonello VM, Oliveira MAC. Advanced practice nursing: a possibility for Primary Health Care? Rev Bras Enferm. 2018;71 Suppl 1:716-21. DOI: http://dx.doi.org/10.1590/0034-7167-2017-0672 